\title{
MEMÓRIA E FONTES ICONOGRÁFICAS: OS DESAFIOS PARA A PESQUISA EM HISTÓRIA DA EDUCAÇÃO
}

\section{Memoirs and iconographic sources:challenges for educational history researches}

Resumo

Teresa Jussara Luporini ${ }^{1}$

A prática de análise de documentos tem colocado os historiadores da Educação diante de múltiplos desafios: o contato com arquivos públicos e particulares, as políticas adotadas para a sua manutenção assim como os procedimentos utilizados para o atendimento ao público especializado e o domínio de fundamentos teónicos e definição de procedimentos metodológicos para proceder ao estudo de documentação/linguagens específicas. O presente trabalho objetiva analisar as possibilidades de utilização de registros fotográficos como fonte de pesquisa em estudos históricos relativos à Educação. A partir da caracterização dos materiais coletados pelo GT dos Campos Gerais do Paraná (UEPG) do HISTEDBR, procede-se à reflexão sobre os princípios teónico-práticos adotados para a análise da massa documental arrolada. A análise dos registros fotográficos amparou-se na compreensão de que a documentação examinada expressa um suporte reconstruído pela especificidade própria à representação do instrumento que a produz: a câmera fotográfica. Tal reflexão reconhece a natureza da fonte documental - a fotografia - que marca a histónia contemporânea pela possibilidade de definir a "veracidade" de realidades passadas, perenizando 0 vivido e criando uma memória futura que passa a distinguir esse período histórico daqueles que o antecederam. A contextualização dos registros fotográficos revela tanto aspectos de organização, controle e disciplina presentes no ambiente escolar quanto a tradição das fotos oficiais, retratando grupos de alunos e professores de forma unida, hierarquizada, expressando uma identidade coletiva, exemplar para a comunidade onde convivem, demonstrando união e boa convivência, desconsiderando, assim, a teia de relações sociais que produz tensões e conflitos. O estudo contribui para o aprofundamento da compreensão sobre o contexto da criação e desenvolvimento do sistema escolar na região dos Campos Gerais, na primeira metade século XX.

Palavras-chave: Educação; Memória; Fotografia.

1 Doutora em Educação - Administração e Supervisão Educacional, professora do Programa de Pós-Graduação em Educação das Faculdades Católicas Integradas de Palmas - Rua Dr. Bernardo Ribeiro Viana, 903, Centro, CEP: 85555-000, Palmas/PR

E-mail: teju@interponta.com.br 


\section{Abstract}

Practices of documents analyses has been put the educational historians in face of multiple challenges: contact with public and private files; the policies adopted for its maintenance as well as the procedures adopted to attend specified public; the domination of theoretical foundation and also the definition of methodological procedures to proceed the study of the specified documents/languages. This work tries to analyse the possibilities of use the photograph records as source of research about history studies related to Education. From the collected material organised by the GT dos Campos Gerais do Paraná (State University of Ponta Grossa) from HISTEDBR, the reflexion done about the theoretical/practice principles adopted for the analyse of the amount of the collected documents. The analyse of the photographic records was based on the comprehension that the examined documents show a support rebuilt by the specification of their producer that is the photographic camera. This reflexion recognises the nature of the documentary source- the photography -which marks the contemporary history by the possibility of definition of the truth from past realities, making things eternal and creating a future memoir which could distinguish the present historical period from the ones that have preceded it. The contextualization of the photographic records reveals the organisation, control and discipline present at the scholar environment as well as the tradition of the official photos, showing students groups and teachers, in an united form, organised into a hierarchy expressing a common identity, which is example for communities where they live, showing union and good closeness, overlooking, this way, the net of the social relation which produce tension and conflicts. The study has contributed to improve the comprehension about the context of creation and development of the scholar system in the Campos Gerais region, in the first half of the $20^{\text {th }}$ century.

Keywords: Education; Memoir; Photography.

Para o historiador, os sinais de vida latente, congelados numa fotografia são índices do mundo, do passado que se busca compreender e podem se transformar em testemunho e representação de uma realidade a ser reconstruída. Por isso, antes de mais nada, constituem um problema para o conhecimento histórico (ARRIGUCCI JR, 1993).

A prática de análise de documentos têm colocado os historiadores da Educação diante de múltiplos desafios: o contato com arquivos públicos e privados, as políticas adotadas para a sua manutenção assim como procedimentos utilizados para atendimentos ao público especializado e o domínio de fundamentos teóricos e definição de procedimentos metodológicos para proceder ao estudo de documentos/linguagens específicas.

A reflexão sobre tais eixos de discussão está referenciada, neste artigo, pela experiência vivida no grupo de pesquisa "História, Sociedade e Edu- 
cação" - HISTEDBR - mais especificamente no Grupo de Trabalho, GT Campos Gerais do Paraná, da Universidade Estadual de Ponta Grossa (UEPG), há 12 anos em atividade, promovendo pesquisas tanto em nível da graduação quanto da pós-graduação lato e stricto sensu. Também, mais recentemente, no GT-Palmas das Faculdades Integradas Católicas de Palmas - FACIPAL - que a partir de 2002 passou a integrar o HISTEDBR, sediado na UNICAMP.

\section{Os Arquivos e a Documentação}

A crescente produção de registros que a revolução documental do mundo contemporâneo produziu demanda para arquivos e bibliotecas a utilização de procedimentos de catalogação e classificação cada vez mais sofisticados, contribuindo para o seu detalhamento de modo a permitir rápido acesso a materiais de pesquisa.

Entretanto, essa perspectiva relacionada à referenciação e à localização de documentos, além de criar ainda maior quantidade de materiais, exige o trabalho de profissionais qualificados e processos meticulosos que oneram 0 labor cotidiano de equipes inteiras em termos de tempo e especialidade.

Considerando a realidade institucional dos arquivos públicos e particulares consultados na produção de pesquisas dos GTs já referidos, cabe destacar as dificuldades observadas tanto no que se refere à equipamentos e infra-estrutura quanto aos recursos humanos e políticas institucionais.

Nesse sentido é importante indicar que as fontes utilizadas como suporte para a construção da História estão relacionadas a uma política cultural, de preservação, enquanto patrimônio histórico-cultural, determinando, portanto, processos que indicam como tais fontes são selecionadas, conservadas, descartadas e/ou socializadas.

Entender as fontes na perspectiva de patrimônio histónico-cultural implica inseri-las não só no contexto das políticas educacionais, como também, nas políticas de preservação da memória, um dos direitos culturais do cidadão (os quais sejam: 0 de acesso à cultura, o de produzir a cultura e 0 direito à memória).

Embora grande parte da literatura que trata da temática indique a falta de uma política de preservação de fontes de modo geral e de fontes educacionais de modo particular, é possível afirmar que existem elementos que caracterizam o crescimento da consciência em relação ao patrimônio, não só no Brasil como em toda a América Latina.

O primeiro deles é o seu caráter abrangente que se manifesta na própria conceituação do termo, que recentemente passou, na bibliografia da área, a ser entendido não apenas como patrimônio histórico, mas como patri- 
mônio cultural. Isso denota um distanciamento de um enfoque limitador, centrado em aspectos apenas históricos, estéticos e oficiais e uma aproximação com outras áreas que passam a qualificar o termo - edificado, natural, ecológico, urbano, iconográfico e outros, resultando, portanto, na expressão patrimônio cultural, que não deixa de incluir o histórico, mas que não está centrado exclusivamente no histórico.

Outro elemento a ser considerado refere-se à seleção de fontes a serem preservadas pela possibilidade concreta de intervenção de diferentes segmentos da população e a consciência dessa mesma população, de que pode interferir na definição de estratégias para a preservação e, portanto, para a formulação de políticas culturais que determinam o sentido e a ação de órgãos oficiais.

Nessa perspectiva, destaque-se a diferenciada capacidade dos diversos grupos sociais de se apropriarem da herança cultural. A participação desigual se reflete na hierarquização dos suportes culturais. Mesmo legislações democráticas de órgãos oficiais que legitimam diferenciados modos de organização e expressão da vida social, não evitam o acesso preferencial dos grupos sociais que se colocam hegemonicamente na produção e distribuição de bens culturais. Assim, a essência da desigualdade na composição do patrimônio, a partir de fontes selecionadas, coloca a perspectiva de que ele seja estudado como arena política em que se confrontam diferentes visões dos grupos sociais, presentes na sociedade contemporânea.

Tais circunstâncias devem ser levadas em conta quando se processa o levantamento e catalogação de fontes, pois essas ações resultam numa seleção de documentos de diferentes naturezas, representativas de diferenciados grupos sociais, que se colocam como desafios ao historiador ao utilizá-los como suporte de sua atividade intelectual.

Para além de tais obstáculos reiteradamente indicados pelos pesquisadores, não se pode deixar de destacar os esforços observados por parte de alguns profissionais para preservar a documentação que se encontra, majoritariamente, sob a guarda do poder público, sempre às voltas com verbas restritas e toda ordem de empecilhos operacionais.

Embora com todas essas dificuldades, deve-se incluir nessa reflexão as possibilidades de utilização das novas tecnologias e dos suportes digitais delas decorrentes, sua constante e rápida obsolescência exigindo a constante atuação de informações.

Considerando a realidade regional e especialmente dos arquivos escolares em que se circunscreve o trabalho dos pesquisadores da UEPG e da FACIPAL pode-se afirmar que a massa documental arquivada e consultada na pesquisa realizada por Luporini (1997), sobreviveu a uma trajetória pontuada por percalços de ordem (ambiental e humana), produzindo, portanto, uma 
forma de seleção tanto no que se refere à teoria das três idades (linguagem técnica definida legalmente para orientar o descarte de documentos) quanto uma visão equivocada, vigente no contexto de ambientes pouco especializados, de preservação de documentos representativos apenas do universo histórico e político.

Deve-se pontuar, ainda, que tais arquivos apresentam diferenciadas espécies de registros: material escrito, impresso, iconográfico, artefatos, instrumentos.

Entretanto, quando ocorre o zelo na preservação, atinge especialmente os documentos oficiais e que refletem o trabalho administrativo da escola: atas de reuniões pedagógicas, de pais e mestres, da cooperativa escolar, de solenidades, termos de visitas, registros de ocorrências de alunos, funcionánios e professores, termos de posse e exercício, diários de classe, diários oficiais, cópias de regulamentos, decretos e resoluções.

É essa perspectiva histórica e administrativa que prejudica a preservação de outros documentos que referenciariam o cotidiano escolar como cadernos e trabalhos escolares, produções docentes, entre outros.

Portanto, as pesquisas produzidas a partir de tais fontes estão limitadas às bases documentais, caracterizadas pelo contexto que interfere na composição dos arquivos, sem desconsiderar outras formas de registro como a história oral, por exemplo, e que conforma uma visão de realidade espaçotemporal.

\section{Memória e fontes documentais}

Recentemente se observa, em nível nacional, a um movimento da sociedade dirigido à preservação da memória de famílias (especialmente de imigrantes), de instituições, de caminhos, de ruas, de praças, de bairros, de antigas fábricas, de estações ferroviárias desativadas e de tantos outros símbolos da presença material do homem. Tal movimento é considerado pelo historiador francês Pierre Nora (Nova História) como expressão da "aceleração da História", fenômeno vivido nos tempos atuais em que a consciência de ruptura com o passado em função da mundialização, da democratização, da massificação e da mediatização, criou a necessidade de organizar arquivos, registrar comemorações, assegurar identidades, isto é, criar "lugares da memória" como espaços que retêm evidências do viver humano.

Nora (1984) define a diferença entre memória e História, as quais embora articuladas, possuem características bem definidas: 
- memónia é a vida, emerge de um grupo que ela une, é múltipla, coletiva, plural e individualizada, é afetiva e mágica, se enraiza no concreto, no espaço, no gesto, na imagem, no objeto; a materialização da memória está representada nos museus, arquivos, bibliotecas, centros de documentação e bancos de dados;

- História é uma representação do passado, é operação intelectual que demanda análise e discurso crítico, possui vocação universal, liga-se às continuidades temporais, estabelece relações, trabalha com o relativo; a materialização da História ocome por meio da produção do conhecimento histórico.

Percebe-se, portanto, que as ações de preservação de identidades étnicas, institucionais, políticas, urbanas, locais, entre outras, são projetos de preservação de memória, pois valorizam narrativas, resgatam documentos e objetos, criam símbolos comemorativos, numa dimensão intrínseca, que se basta a si mesma, que pertence a determinado grupo social/institucional, que não se preocupa em promover movimentos de análise, reflexão e articulação com contextos e estruturas históricas, socioeconômicas e/ou políticas.

Nessa perspectiva é a ação mágica e afetiva da memória que une 0 grupo o qual identifica culturalmente, como por exemplo, os descendentes de famílias de imigrantes; ou ainda, o velho funcionário que preserva os rituais da antiga fábrica, transformada em museu, revivendo com nostalgia os tempos idos de um trabalho que lhe trouxe significação à vida cotidiana. Esse movimento não raras vezes se expressa sob a forma mítica e de construção de uma saga cujo herói passa a ser o patriarca da família, pioneiros ou trabalhadores em luta pela reivindicação de seus direitos.

Discutir a relação História-memória é bastante pertinente para a compreensão das possibilidades de desenvolvimento de projetos que se reportam à História Local e o que a mesma representa em termos de fontes e de compreensão do modo de pensar e viver, de conhecimento de especificidades histórico-culturais, presentes quando se elabora a História Regional e Local, em contato com os arquivos escolares.

Detalhar o desenvolvimento de uma comunidade, segundo Rodrigues (1982), pode ser expressiva contribuição à História Nacional. Embora limitada pelo perigo da fragmentação, a História Local apresenta os acontecimentos do cotidiano, do homem comum coletados nos arquivos das famílias ou das instituições e na memória dos idosos. Permite, ainda, a percepção dos costumes, das idéias, da mentalidade vigente num determinado espaço histórico-cultural.

As fontes relativas à História Local podem ser muito variadas, favorecendo uma noção mais imediata do passado, valorizando as coisas simples da vida cotidiana que representam os fazeres e saberes de uma localidade, pois, 
segundo Samuel (1990), o ambiente local é permanente desafio para as pessoas que se ligam afetivamente ao local onde residem, lembrando/questionando como viveram seus antepassados, valorizando por meio de aguçado senso de herança documentos escritos, fotografias, cartas, registros de natureza bastante diferenciada.

É nesse sentido que um projeto de história local pode originar seus próprios arquivos e fontes, numa verdadeira miscelânea de documentos obtidos nos locais mais improváveis. Também, pode-se utilizar da história oral. Nesta perspectiva, os arquivos locais assumem dimensão muito importante; inclusive, os arquivos escolares que podem ser utilizados pedagogicamente (LUPORINI, 1994).

Apesar de todas essas possibilidades é preciso ter clareza que os acontecimentos locais não são obrigatoriamente representativos de uma conjuntura regional ou mesmo nacional. Assim, consideram-se as suas limitações, seja pela própria natureza do tema ou pela impossibilidade de preencher um quadro histórico em todas as suas implicações conjunturais.

\section{A fotografia como fonte documental}

A massa documental arrolada pelo GT Campos Gerais do Paraná da UEPG, objeto do presente trabalho, caracteriza-se por registros do século XX.

Os documentos catalogados na primeira etapa de investigação (19921997), em arquivos públicos e privados, especialmente os escolares, constituem registros variados, de diferenciada natureza.

A pesquisa realizada arrolou massa documental riquíssima, oportunizando a realização de uma série de investigações sobre a memória da educação local e regional, circunscrita ao material bibliográfico até a década de 1950, em função de que o número de volumes em cada edição era diminuto e, também, porque o período indicado possibilita a oportunidade de analisar a introdução do ideário da Escola Nova. Para a documentação escolar, consideraram-se, ainda, os materiais até a década de 1970, quando, com a implantação da Lei 5692/71, houve mudanças no tipo de documentação escolar exigido, com a presença marcante do tecnicismo.

Dentre os registros catalogados foi possível detectar a presença dos seguintes materiais:

- fontes manuscritas referentes a atas de variadas naturezas: de agremiação estudantil, de reuniões pedagógicas, de reuniões de professores, de exposições, de patrimônio, de associações de pais e mestres, de jogos estudantis, de solenidades, de conselhos de classe, de conselhos de disciplina, de exames, assim como termos de visitas, portarias e avisos, certidão de exames 
e livro de penalidades, sanções e ocorrências; também se registram provas, diário de lições e relatónios (de atividades realizadas, financeiros, da vida cotidiana da escola);

- livros técnicos sobre variados assuntos, especialmente os destinados a professoras da escola primária e alunos de Escola Normal ou Escola de Professores, como os de Didática, Pedagogia, Puericultura, Educação Moral e Educação Cívica, Filosofia, Educação Doméstica, Psicologia, Sociologia, História da Educação, Metodologia das diferentes disciplinas, além dos livros dedicados ao ensino primário, secundário, supletivo, ensino profissionalizante (comercial, ferroviário, militar), os de temática específica como Escola Nova, Escola Ativa e, ainda os livros que articulam Jornal e Educação, Rádio e Educação, Cinema e Educação, Teatro e Educação, Imprensa Escolar;

- cartilhas;

- livros didáticos das diversas disciplinas (Português, Matemática, Aritmética, Desenho, Geometria, Física, História, Geografia, Biologia, Ciências, Educação Física, Latim) e cartilhas;

- revistas educativas, calendário e dicionários;

- fotografias;

- álbuns (comemorativos do Paraná, de Ponta Grossa).

A construção do processo de intelegibilidade das fontes permitiu detectar que o material catalogado oportuniza uma série de investigações abrangendo, especialmente, quatro momentos distintos e articulados:

- parte do contexto da Primeira República, no cenário dos embates político-pedagógicos articulados à Pedagogia Tradicional, Nova e Libertária;

- a Segunda República, no panorama da política educacional dos anos 30;

- o Estado Novo;

- o período da redemocratização.

Do primeiro período destacam-se, como exemplo, os consistentes "avisos da direção da escola" do Grupo Escolar Senador Correia, nos quais o diretor, um normalista, expressa a metodologia que considera adequada a ser adotada pelo corpo docente, tomando por base os "cinco passos formais de Herbart". Nessa perspectiva enfocava-se o ensino articulado ao desenvolvimento do caráter em três estágios e que se inseria, grosso modo, na Pedagogia Tradicional, na tendência da "pedagogia como ciência da educação": a psicologia da Educação (LUPORINI, 2003).

Ainda do primeiro período apontam-se inúmeros exemplares bibliográficos dos jovens intelectuais dos anos 20 deste século - Anísio Teixeira, Fernando de Azevedo e Lourenço Filho, responsáveis por reformas educativas estaduais ocorridas nesse espaço temporal. Pode-se afirmar que a Pedagogia "Nova" que representavam constituiu-se num pensamento educacional amplo 
abrangendo tanto uma teoria de educação, quanto organização escolar e metodologias próprias. Também merecem referência os escritos de Dewey, Durkeim e Claparéde.

Esses materiais bibliográficos catalogados são fonte inestimável para compreender o pensamento educacional vigente no período de 1920-40 e a compreensão desse contexto em nível regional pode ser complementada pela análise dos "livros de avisos", "livros de reuniões pedagógicas" e fotografias catalogadas.

Ressalve-se que a maionia desses materiais encontra-se em bibliotecas de escolas que abrigaram antigas escolas normais e, também, nos grupos escolares-modelo que mantinham, para estudo, a biblioteca do professor primário.

Como indicado anteriormente, os registros catalogados se referem aos anos iniciais do século XX. Isso ocorreu porque foi apenas em 1838 que, tardiamente, foi concedida a autorização para o funcionamento de escolas particulares, não havendo escola pública na Freguesia de Ponta Grossa; assim mesmo, para o funcionamento de escolas particulares apresentavam-se as seguintes exigências: o professor deveria pertencer ao sexo masculino e prestar exame de suplência em São Paulo, capital da Província (O Paraná foi elevado à categoria de província em 19/12/1953).

O primeiro registro da existência de escola pública no município, segundo Holzmann (1975), data de 1879, sendo que a nomeação do primeiro professor para atuar em escola pública é de 1892 (Felício Francisquini, transferido de Assungui). Ainda segundo a autora, somente em 1907 será nomeada a primeira professora normalista, Otacília Hasselmann de Oliveira, para lecionar na Casa Escolar do Governo, sendo construído prédio próprio para a mesma em 1908.

Em 1912, o poder público, pela união de duas classes isoladas, criou o Grupo Escolar n. 2 (atual Colégio Estadual Senador Correia).

Nesse período, segunda metade do século XIX, funcionaram inúmeras escolas particulares e algumas poucas classes públicas, assim como escolas destinadas aos filhos de imigrantes sob os cuidados de entidades religiosas e de associações (alemães, russo-alemães e poloneses).

Embora a existência de iniciativas educacionais na região se reportem ao século XIX, o sistema educativo oficial se afirma com a interiorização representada pela criação do ensino normal em 1924 e do ensino ginasial em 1927 (atual Colégio Estadual Regente Feijó). Portanto, as fontes documentais enquanto suporte para a História da Educação Local/Regional expressam as características desse período histórico.

No desenvolvimento da investigação foi recuperado, também, um significativo acervo fotográfico de escolas, demandando especial referência sobre a sua utilização enquanto documento. 
No que se reporta aos materiais iconográficos merece destaque uma série de fotografias da Escola Normal de Ponta Grossa, atual Instituto Estadual de Educação César Prieto Martinez, fundada em 1924 e do Grupo Escolar "Senador Correia", criado em 1912, como já se referenciou.

São registros de autoria do fotógrafo Rauli Bianchi, cujo arquivo retrata a vida cotidiana da cidade, iniciando ns anos finais do século XIX e percorrendo toda a trajetória do século XX; esse fotógrafo foi sucedido na atividade profissional por seu filho Raul Bianchi. O Foto Bianchi localizava-se na rua Sete de Setembro, no 592, em Ponta Grossa. Esse acervo fotográfico foi adquirido pela UEPG no início de 2000, passando a compor os seus arquivos históricos.

A análise do material fotográfico catalogado pelo GT Campos Gerais conforme Luporini, (1977) demandou a necessidade de aprofundamento de estudos sobre o caráter dessa fonte documental, iniciados ainda na década de 80 quando da realização da investigação "Pesquisando e compreendendo História: uma experiência com alunos de 8a série" (LUPORINI, 1989).

Naquela oportunidade, os registros fotográficos se referiam à vida cotidiana da cidade nas décadas 1910-1920, centrando-se na memória da Escola Estadual Senador Correia.

Considerando que o sistema educacional na cidade completou o ciclo de criação e funcionamento do ginásio e do curso normal nos anos 20 e 30, os registros fotográficos se enraízam nessas duas décadas, sem desarticular-se dos anos finais da década de 1910 quando foi oficialmente instalado 0 curso primário.

A análise dos registros fotográficos amparou-se na compreensão de que a documentação examinada expressa um suporte reconstruído pela especificidade técnica própria à representação do instrumento que a produz: a câmera fotográfica.

Tal reflexão reconhece a natureza da fonte documental - a fotografia - que marca a história contemporânea pela possibilidade de definir a "veracidade" de realidades passadas, perenizando o vivido e criando uma memória futura que passa a distinguir esse período histórico daqueles que 0 antecederam (CIAVATTA, 2002).

Nesse sentido, deve-se reconhecer a produção, circulação e consumo de fotografias como um processo característico do contexto técnico que eleva esse tipo de registro à condição de identificar e construir imagens individuais e coletivas, de grupos, de classe, de nação.

Assim, a fotografia entendida como fonte documental, ultrapassa a condição de apresentar uma simples descrição para expressar em sua leitura valores, tradições, comportamentos presentes em diferentes tempos e temporalidades que traduzem modos de viver, entender a realidade perdurando como elemento de coesão de grupos sociais no presente. 
Apreender a imagem fotográfica exige a elaboração de um mapeamento informado por procedimentos teórico-metodológicos. Isso se coloca em função da magia intrínseca presente na contemplação da fotografia, muitas vezes encarada como "janela entreaberta" sobre o passado. A análise de fotos, enquanto fonte, exige rigoroso trabalho interpretativo, considerando que a imagem recria a realidade que ao mesmo tempo se expressa/dissimula num retângulo de papel em duas dimensões.

Assim, afastando-se do realismo fotográfico, largamente utilizado nos estudos de arquitetura urbana, busca-se penetrar a arqueologia da imagem, reconstruindo a teia de relações sociais a ela subjacente. Isso significa o esforço de articular os significados que expressam as partes e o todo, a ambigüidade, a subjetividade presentes na especificidade dessa fonte documental que se articula pela interpretação de quem a produz - o olho humano - e se circunscreve enquanto aparato técnico - a câmera fotográfica.

Analisada enquanto fonte documental, como afirma Leite (1993, p. 12):

é ilusório pensar-se que as imagens se comuniquem imediata e diretamente ao observador, levando sempre vantagem à palavra pela imposição clara de um conteúdo explícito. Na maioria das vezes, ao contrário, se calam em segredo, após a manifestação do mais óbvio: por vezes (...) desafiadoras em sua polissemia; por vezes, em seu isolamento, se retraem à comunicação, exigindo a contextualização, única via de acesso seguro ao que possam significar. (...) são difíceis de se deixarem traduzir num código diverso como o da linguagem verbal. Quer dizer: a fotografia deve ser submetida a uma abordagem crítica para que de fato se revele, e o historiador se vê a si mesmo envolto numa teia de equívocos se não se atém obstinadamente ao rigor do método crítico de aproximação às imagens que ao mesmo tempo podem muito dizer e calar. Mas de pouco vale o método, se não se é sensível o olhar que se debruça sobre o outro olhar de outrora e que deve portar de algum modo, como diante do poema, a chave para uma interrogação, a resposta para um enigma que o aguarda em silêncio.

Assim, como com a documentação escrita busca-se a compreensão do não explícito, o espaço das entrelinhas; adotando-se esse mesmo procedimento com relação à fotografia deve-se considerar que, aparentemente, se trata de comunicação imediata da imagem, mas, existem significações que necessitam ser construídas, pois não se expressam diretamente, uma vez que se for superficialmente lida, a fotografia silencia, torna-se opaca. "Somente uma pesquisa de forma e conteúdo, uma desconstrução de seus elementos e um estudo das imagens mentais que sugerem conseguem desvendar globalmente os níveis de sentido das fotografias já feitas, a que se tem acesso" (LEITE, 1993, p. 17). 
É nessa perspectiva que a compreensão dessa fonte documental não deve desconsiderar a natureza diferenciada que representam os códigos que permitem a passagem das imagens para as palavras, nem a consciência de que o que se observa visualmente e se expressa verbalmente ou por escrito é 0 contexto reduzido do espaço geográfico do ponto de vista cultural e ideológico, num momento determinado.

Desse modo, a observação atenta e especializada é capaz de apreender por meio dos aspectos técnicos como o enquadramento, os planos, a horizontalidade/verticalidade, o formato, dados relativos a características do objeto, desenvolvimento urbano, indumentária, comportamentos e representações, entre inúmeras possibilidades.

Esses aspectos é que orientam a ordenação de fotografias, normalmente definidas apenas pela análise de dados espaciais e temporais.

No que concerne às fotos de família, deve-se considerar que são registradas para a posteridade uma relação dos entes queridos que vivem limitados a padrões considerados dentro da "normalidade"; os que não se submetem a tais rituais são "esquecidos", escondidos, produzem os "silêncios" das fotografias, assim como alguns recantos da casa, casamentos não aprovados, situações cotidianas consideradas de menor expressão.

Com relação aos registros escolares é fundamental a reflexão sobre a utilização de variadas fontes que não apenas os documentos oficiais, como legislação e relatórios. É claro que tais materiais, mesmo carregando essa característica de oficialidade, podem ser utilizados desde que se contextualize a sua existência, indicando os sujeitos que colaboraram na sua produção, os destinatários de tais mensagens e a sua capacidade de intervenção.

Da mesma forma se procede com as fotografias, inseridas em álbuns "institucionais". Elas refletem uma linha de inteligibilidade semelhante à da história oficial. Retratam datas comemorativas, rituais escolares, autoridades, solenidades, os fatos "extraordinários", havendo poucos registros do cotidiano, das práticas escolares tanto pedagógicas quanto das normas de vigilância e disciplina presentes no ambiente educativo, mesmo no que concerne aos espaços físicos das instituições que refletem uma forma de ordenação dos processos educativos.

As fotos selecionadas para análise, na pesquisa realizada, objeto do presente estudo, retratam situações diferenciadas: fachadas frontais ou laterais de prédios escolares, espaços internos que se caracterizam pela falta de presença humana apresentando-se vazios, desabitados, e ainda, situações do interior da sala de aula e do recreio.

Diante das fachadas das escolas em algumas fotos, entretanto, aparecem grupos de professores cumprindo os rituais escolares oficiais e/ou comemorativos. 
Esses registros fotográficos, que retratam prédios no seu aspecto exterior/interior e grupos de professores e alunos foram utilizados nos relatórios dos inspetores da Instrução Pública do Estado do Paraná, nas décadas estudadas.

Parte desse material compõe os arquivos escolares catalogados durante a pesquisa. Devido ao seu precário estado de conservação uma parte dos registros foi reproduzida pelo fotógrafo Raul Bianchi, em 1994. Os recursos foram providos pela UEPG e após a análise do material as fotos foram encaminhadas para arquivo em suas escolas de origem ${ }^{2}$.

Para a composição de critérios a adotar para a análise das fotos ficou definido que os mesmos não se constituiriam numa série de instruções passíveis de aplicação às fontes documentais examinadas, uma vez que havia uma complexidade analítica que resultaria na produção de conhecimento. Conhecimento este, que dependeria de perguntas significativas articuladas a uma dada realidade. Nesse sentido, considerou-se toda a subjetividade do pesquisador presente na operação analítica, de caráter epistemológico e não simplesmente instrumental.

Os referenciais teóricos estudados, como encontrados em Oliveira Júnior (1994); Leite (1993); Chartier (1990); Essus (1990) apontam para a possibilidade de análise da fotografia como mediação e como um movimento de reconstrução histónica articulados à complexidade da produção do conhecimento.

Esses autores apresentam em comum a oposição à interpretação da fotografia de modo positivista, como simples reflexo da realidade, elevando-a ao estatuto de testemunho neutro e imparcial; embora apresentem concepções de representação próprias, destacam os aspectos históricos e técnicos da fotografia como suporte para tais representações.

... metodologicamente Chartier sugere que na análise, sejam consideradas as posições sociais e interesses dos grupos que se apropriam e utilizam da imagem; (...) Essus trabalha com a categoria poder e dominação analisando, principalmente, o poder simbólico dos bens culturais produzidos e/ou apropriados pelo Estado, pela grande imprensa ou pela família: (...) vê na intertextualidade, a recorrência a outras fontes referentes ao mesmo tema como recurso para a interpretação da imagem fotográfica; (...) Oliveira (...) introduz o conceito de estrutura significante para a interpretação da imagem fotográfica, o que implica a análise do contexto pessoal e social do fotógrafo, os códigos implícitos e não aparentes na fotografia, assim como sua lógica interna de organização (CIAVATTA, 2002, p. 28-29).

2 No sentido de contribuir com a preservação dos registros fotográficos foram envolvidos professores e alunos do Ensino Fundamental e médio que participaram de reuniões nas quais foram divulgadas noções de tratamento dos documentos (higienização e catalogação), além de atuarem como auxiliares de pesquisa. Esses procedimentos estão descritos em Luporini (1994). 
Essa perspectiva teórica foi considerada na construção de procedimentos para a compreensão dos documentos fotográficos que foram analisados, individualmente e no conjunto, procurando-se estabelecer a articulação com o contexto sócio-histórico do panorama educacional da cidade, contribuindo para a percepção de totalidade implícita na singularidade de situações e processos educativos registrados.

\section{0 contexto histórico-educacional e as fontes iconográficas}

A aplicação dos procedimentos teórico-metodológicos indicou a necessidade de construção do contexto histórico de inserção das fotos. Nesse sentido, incluiu-se breve contexto educacional do Brasil e descrição de aspectos socioeconômicos da cidade, na década de 1920-1940, com indicativos da ficha documental do registro fotográfico (cadastro de documentos iconográficos em anexo).

\section{Brasil nos anos 20}

A década de 20 do século XX caracteriza-se, na educação, pela presença sistemática de ideário renovador, que se traduz pelas reformas educacionais ocorridas em vários estados da Federação, inclusive no Distrito Federal. Além disso, registra-se a expansão da literatura na área, assim como a emergência de educadores reconhecidos como profissionais, e ainda, a realização de conferências nacionais por iniciativa da ABE (Associação Brasileira de Educação). Para Monarcha (1989, p.14) ${ }^{3}$ :

De certa maneira, a década de 20 foi palco da difusão do ideário liberalescolanovista e de sua institucionalização; (...) o escolanovismo brasileiro estaria alinhado a outros movimentos de aspirações modernizantes, que buscavam dentro de suas particularidades a sempiterna refundação do tempo social : a Semana de Arte Moderna de 1922; a fundação do Partido Comunista do Brasil, em 1922; o ciclo das rebeliões tenentistas, cujo ápice é a "Revolução de 30 ", etc.

3 O autor oferece uma crítica radical ao escolanovismo no Brasil, desvelando o pragmatismo que caracteriza e domina a literatura sobre essa temática e o período histórico em que se realizou, denunciando a forma como as reformas educacionais ocorridas serviram a um plano de civilidade, urbanidade, racionalidade, submissão ao capital, necessários à inserção do Brasil na modernidade; promove a compreensão da pedagogia da Escola Nova pela via da luta política, criticando a compreensão desse período da história da educação brasileira na perspectiva do positivismo historiográfico. 
Para o autor, a Escola Nova representou a mobilização da sociedade, do ponto de vista político e ideológico, objetivando inserir a educação num patamar moderno, contrapondo-se ao atraso nacional; como suporte para atingir tal objetivo serviu-se da produção cultural, buscando a construção de uma identidade nacional. Laicidade, gratuidade, co-educação, obrigatoriedade, escola única, dever do Estado, educação pública, são os princípios sobre os quais irá assentar-se a Pedagogia Escolanovista.

Tal ideário renovador encontra-se representado nas fontes pesquisadas na Região dos Campos Gerais do Paraná, por meio da literatura, ímpeto reformista e inovador, do registro das práticas docentes realizadas, do controle e do espírito racionalista nas relações de trabalho e poder, da ânsia na formação e contratação de "profissionais" do magistério para levar a cabo a educação das crianças e jovens de maneira "eficaz e competente".

Ponta Grossa - PR (1920-1930)

Na década 1920-1930 são instalados os cursos normal e ginasial. Nesse período a cidade foi governada por Brasílio Ribas (1920-1924), Vitor Antonio Batista (1924-1928) e Elyseu Campos Melo (1928-1930).

Em 1920 a cidade possuía 12.259 habitantes na zona urbana e 15.621 moradores na zona rural. A economia vinculava-se à agropecuária, sendo a erva-mate uma de seus principais produtos agrícolas.

Em 1922 iniciam-se as gestões para a construção da Escola Normal com as desapropriações de terrenos entre a rua Coronel Bittencourt e a Igreja do Rosário, e a rua Pinheiro Machado com a Comendador Bonifácio Vilela.

Nessa década foram criadas, além das escolas já referidas, as escolas públicas dos bairros de Uvaranas (atual Colégio Estadual Gal. Osório) e Oficinas (Colégio Estadual Professor Colares). Também foram criados a Associação Comercial e Industrial de Ponta Grossa, o 13ํㅡㄹ Regimento de Infantaria, o Matadouro Municipal.

Foram ampliadas e urbanizadas as praças Floriano Peixoto (Praça da Matriz) e a Barão do Rio Branco. A municipalidade concedeu auxílio para a compra do Palácio Episcopal. Ocorreu, também, a construção da Catedral de Sant'Ana que passou a ser a sede do Bispado (a Diocese foi instalada em 1930).

Foi fundado o Asilo São Vicente de Paulo e construído o prédio para abrigar o Fórum Municipal.

Foram modernizadas as redes telefônicas e de água e esgotos. Iniciase o contrato com a Companhia Prada de Eletricidade para fornecimento de energia elétrica (CHAMMA, 1990, p.68-78) 
A foto apresenta distribuição harmônica dos professores. A organização do grupo expressa a perspectiva de uniformidade em vários sentidos:

1. a distribuição homogênea das professoras ladeando os dois únicos professores (três fileiras apresentam exatamente o mesmo número de professoras);

2. o uso do uniforme (guarda-pó branco) caracterizando a profissão; época;

3. os sapatos, o penteado definem uma opção e postura feminina da

4. a posição central ocupada pelo diretor da escola (Dr. Meneleu de Almeida Torres, além de professor, juiz de direito), define a hierarquia profissional;

5. a tradição das fotos oficiais, em pose contida, digna para a profissão, ocupando as escadarias que conduziam ao saguão de entrada da escola, permitido apenas aos professores, funcionários, pais e visitantes;

6. o grupo fotografado de forma unida, hierarquizada, diante de seu local de trabalho, expressando uma identidade coletiva, exemplar para a comunidade, demonstrando união e boa convivência.

O grupo de profissionais retratado era oriundo das classes médias da população local; o magistério representa um trabalho considerado adequado para as mulheres naquele período histórico; a escola primária apresentava maioria de professores do sexo feminino; já no ginásio a maioria do corpo docente era constituída por homens.

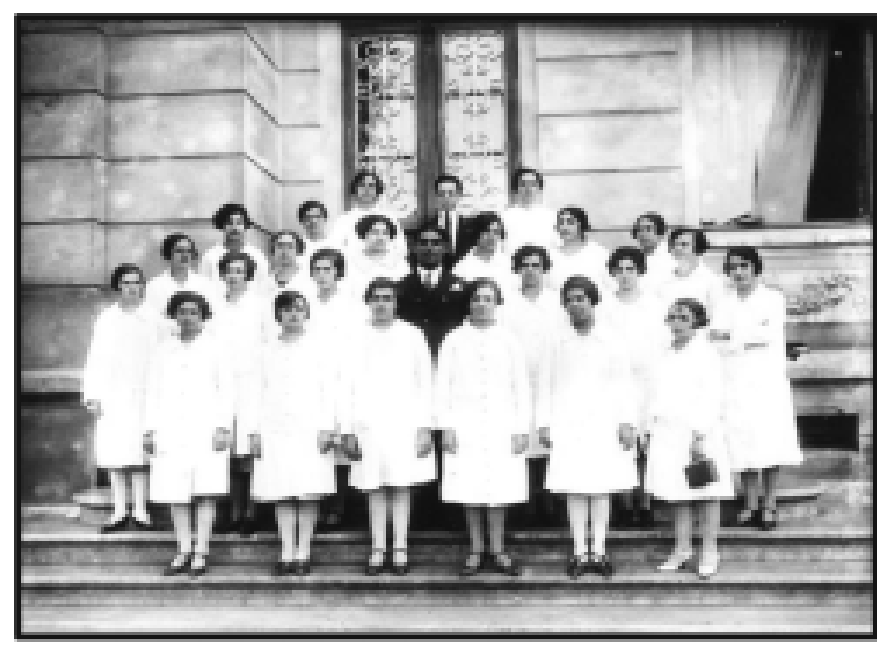

Foto 1 - Corpo docente da Escola deAplicação anexa à Normal Primária de Ponta Grossa (1924) - Escadarias do prédio localizado na Praça Barão do Rio Branco. 


\section{Década 1930-1940}

Vivenciando uma fase política extremamente conturbada com o período ditatorial e, posteriormente o Estado Novo, a cidade foi governada por vários prefeitos, em períodos muito restritos: Bernardo Sávio (1930), Jorge Becher (1930/31), Othon Mader (1931), Brasil Pinheiro Machado (1932), Pedro Sherer Sobrinho (1939). O único mandato longo foi exercido por Albary Guimarães (1934-1945) que o iniciou, por nomeação do Interventor do Paraná, Manoel Ribas. Em 1935 venceu as eleições, permanecendo no cargo até 1945.

Nesse período instala-se o Quartel da 5a Infantaria Divisionária.

Em 1938 é fundada a Faculdade de Farmácia e Odontologia.

Também nessa década é inaugurada a Escola de Trabalhadores Rurais "Augusto Ribas", construído o Quartel do corpo de Bombeiros, o Hospital 26 de outubro, o Aeroporto Sant'Ana. Ainda é readaptada a Praça Barão do Rio Branco para a realização das atividades de Educação Física dos alunos do Ginásio Regente Feijó (cancha de vôlei, basquete e pista de atletismo).

A mensagem expressa pela fotografia é de um ambiente ordenado, solene, grandioso, com vários aspectos estético-espaciais: as cadeiras de espaldar alto alinhadas ao redor da mesa, os quadros de formatura atestando a tradição de formação de gerações, indicando a missão da escola e daqueles que ocupavam essa sala. Expressa, ainda, um arranjo estético que comunica as funções de ordem, disciplina e dignidade do ambiente de trabalho.

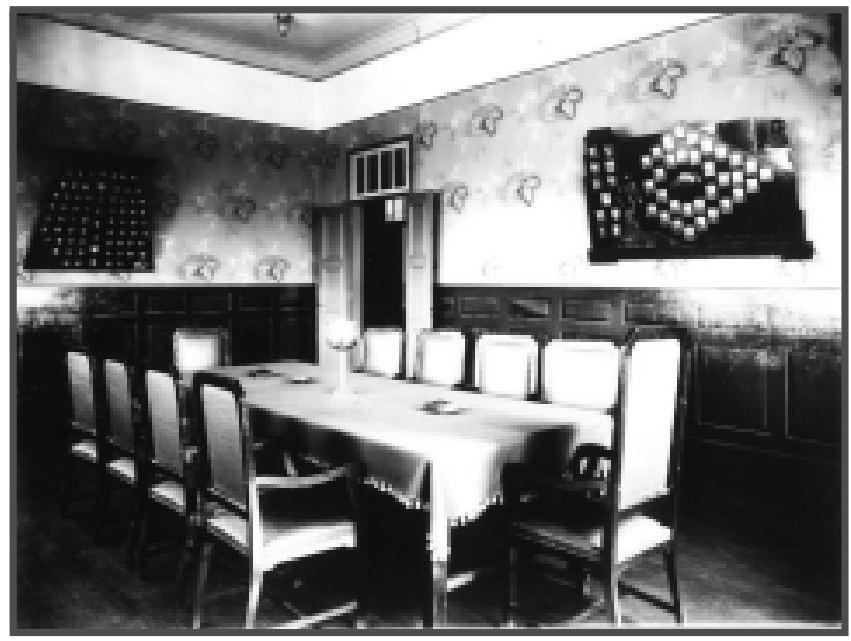

Foto 2 - Sala da Congregação da Escola Normal de Ponta Grossa - 1924 (Prédio localizado na praça Barão do Rio Branco). 
As fotos foram construídas para expressar a monumentalidade da construção, pois havia a necessidade de valorizar o imóvel comprado pelo poder público para servir ao ginásio. Isso ocorreu porque a Escola Normal foi transferida de um prédio próprio, especialmente construído para tal fim, com salas específicas e espaços especiais, inclusive gabinetes médico e odontológico, para uma casa de família (embora um palacete senhorial) anteriormente ocupado pelo ginásio. Também havia o sentido de não desmerecer um nível de profissionalização - o ensino normal - em função de outro grau de ensino como o ginásio que havia crescido muito, obrigando a transferência da Escola Normal, sempre às voltas com a falta de matrículas. Nesse período ocorre, também, o distanciamento das direções das duas escolas, sempre um ponto de conflito entre o diretor do ginásio e o responsável pela Escola Normal a ele subordinada (LUPORINI,1994). O prédio foi recuperado e sua fachada tombada pelo Patrimônio Público do Estado do Paraná, em 1992.

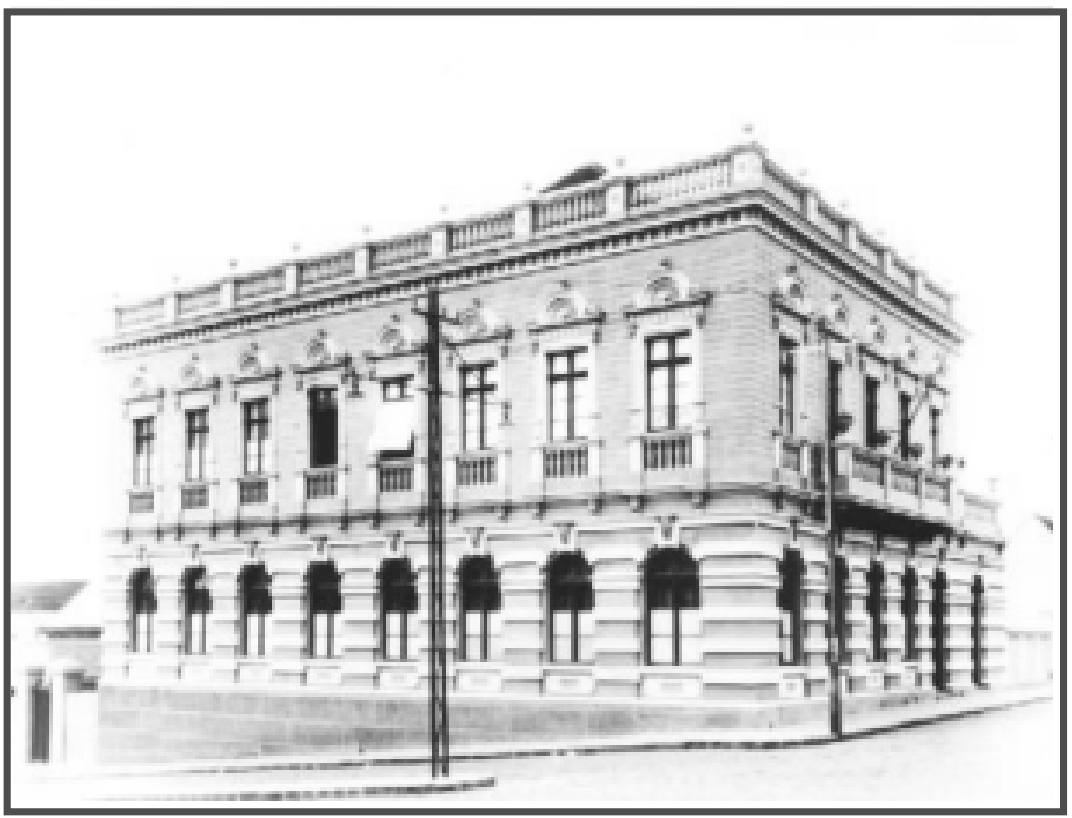

Foto 3 - Fachada do prédio em que funcionou a Escola Normal de Ponta Grossa a partir de 1939, na rua Augusto Ribas esquina com a rua Prof. Colares. 


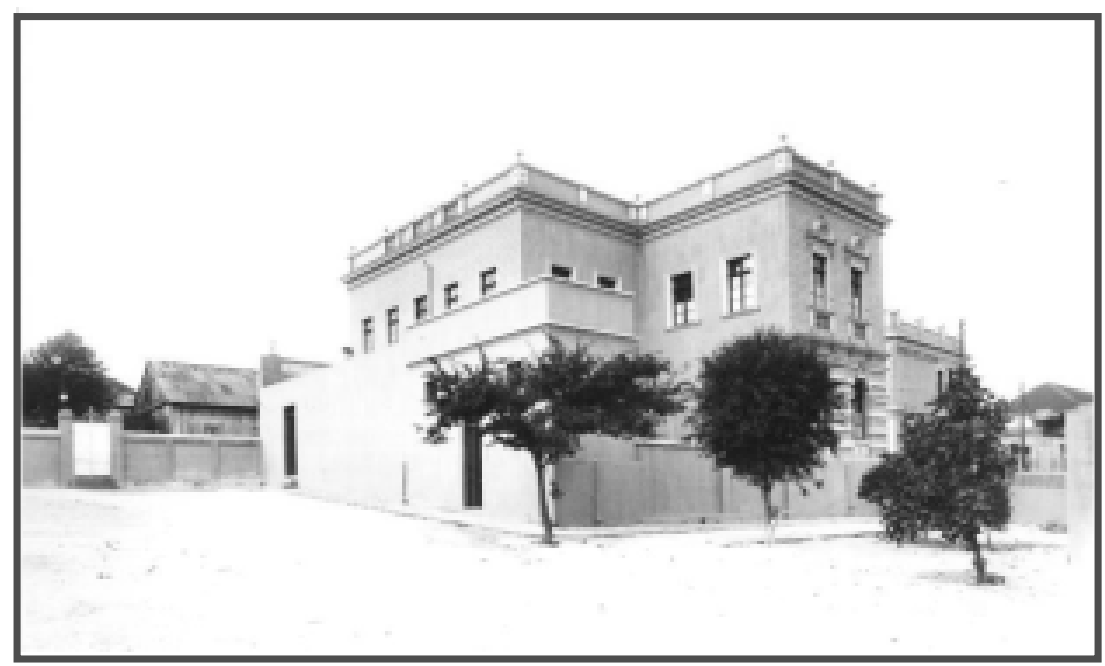

Foto 4 - Perspectiva do fundo prédio da Escola Normal de Ponta Grossa, incluindo o pátio (1939).

As fotos, em tomadas diferenciadas, visualizam a escada e o saguão que antecede a Sala da Congregação da Escola Normal.

As fotos n. 5 e n. ${ }^{\circ}$, valorizando a monumentalidade, projetam os elementos da estética em profundidade, destacando a localização no primeiro andar do prédio e os elementos decorativos do teto.

A foto n. 7 destaca o ambiente da ante-sala com seus objetivos característicos: o chapeleiro, o livro para anotar as presenças. Denota um ambiente que valoriza o oficial, o burocrático. Ninguém adentrava a sala da congregação sem ser anunciado ou determinado.

O fato de situar-se no primeiro andar do prédio, cujo acesso ocorria após percorrer a escada em curva, demonstrava a dificuldade de acesso e preparava para os solenes rituais que lá ocorriam (depoimento de professores da Escola Normal de Ponta Grossa em 05/04/2000). 


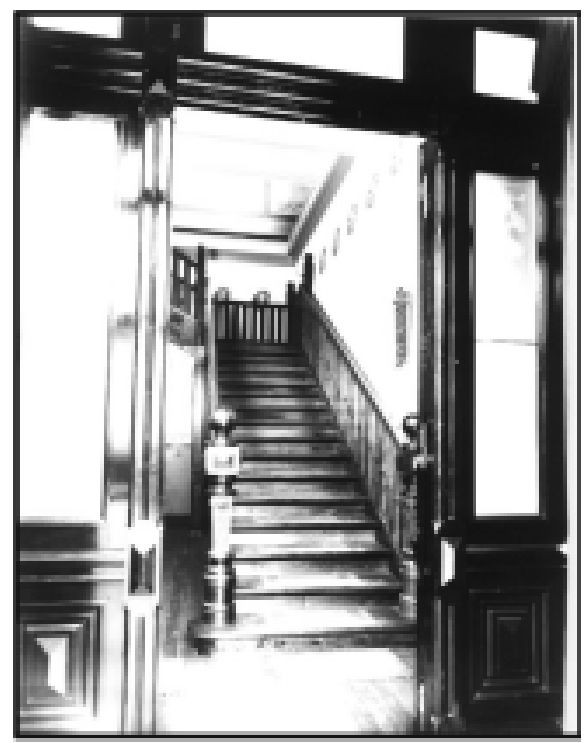

Foto 5 - Escadaria da entrada central do Prédio da Escola Normal (1939).

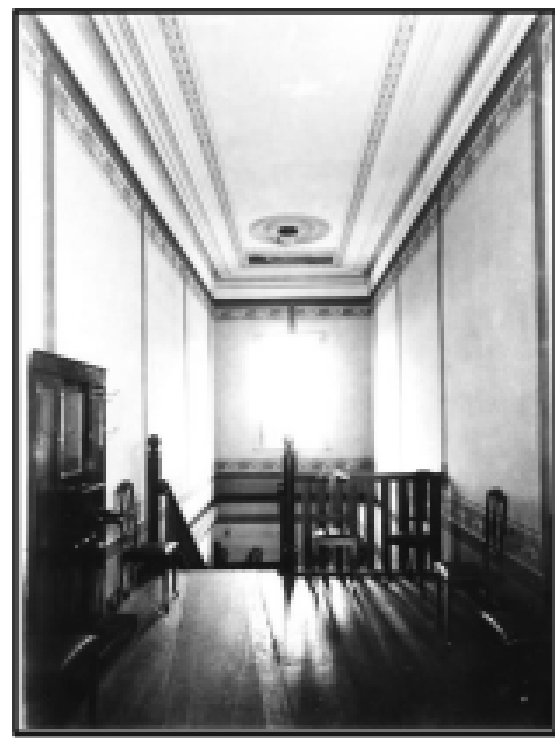

Foto 6 - Entrada do saguão da Sala da Congregação da Escola Normal a partir da visão da escadaria que a ela conduzia (1939).

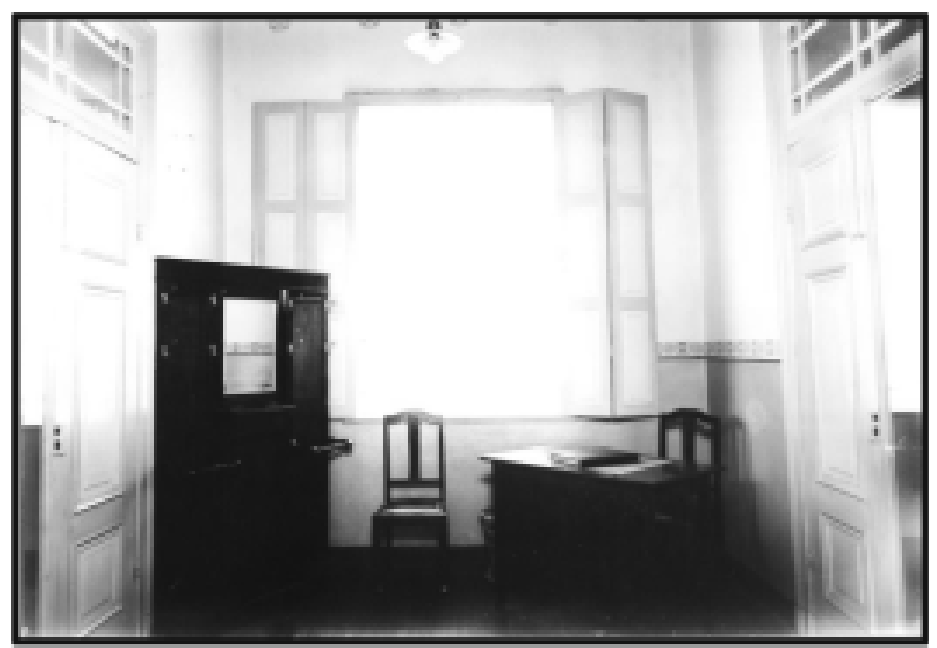

Foto 7 - Ante-sala da Sala da Congregação da Escola Normal (1939). 
O ambiente fotografado revela aspectos de organização, controle e disciplina presentes no ambiente escolar.

Os elementos decorativos - lustres, cortinas, espelho, toalha - revelam uma sofisticação feminina, própria do ambiente do Curso Normal.

A leveza da decoração das paredes, sem esconder o aspecto austero do ambiente, contribuem para iluminar o cômodo.

O plano de tomada valoriza a horizontalidade, produzindo um sentido de profundidade que colabora para a amplitude do espaço fotografado e para a solenidade das decisões ali tomadas.

Essa sala foi recuperada e tombada pelo Patrimônio Público do Estado do Paraná em 1992.

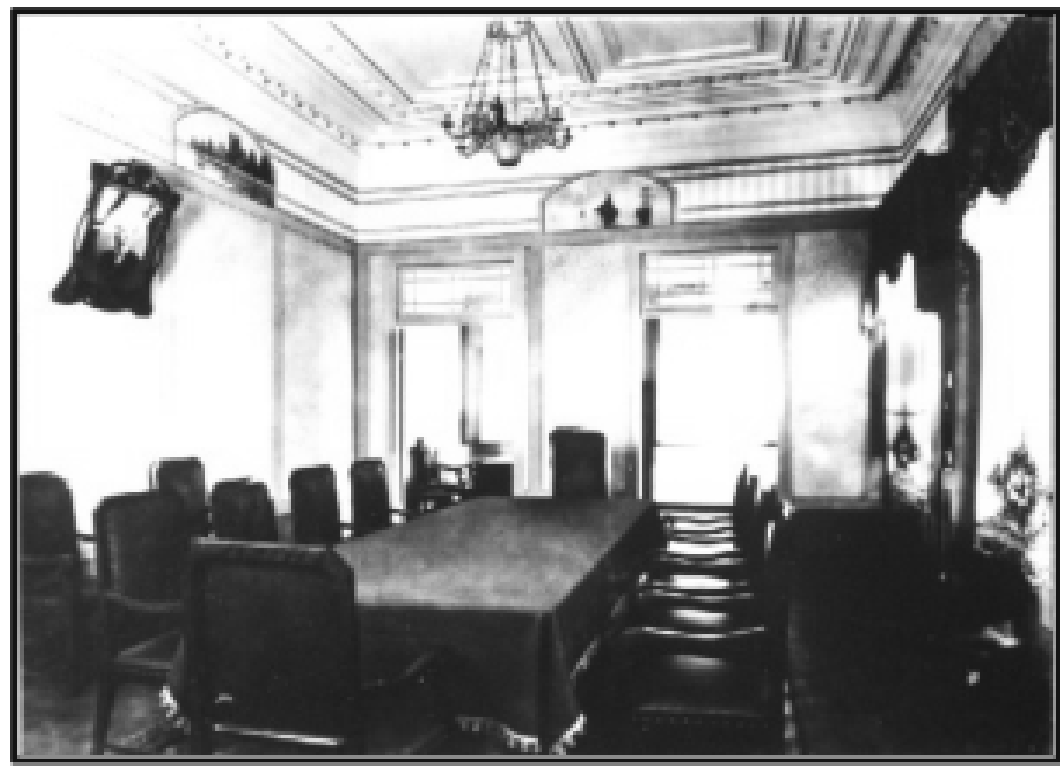

Foto 8 - Sala da Congregação da Escola Normal (1939), localizada na Rua Augusto Ribas, esquina com a rua Dr. Colares. 
O prédio seguia um modelo padrão definido pelo poder público. Essa planta com seis salas de aula e duas salas menores para as atividades administrativas, com instalações sanitárias no fundo e separadas do prédio seguia os padrões postos pelos princípios higienistas em vigor. $\mathrm{O}$ edifício escolar ocupando o centro da praça, onde anteriormente se localizava o mercado municipal, expressava o destaque que o discurso oficial proclamava à instrução pública.

A pequena escadaria que oferecia acesso à entrada principal reproduzia os padrões arquitetônicos vigentes e servia como centro para as fotos comemorativas e oficiais.

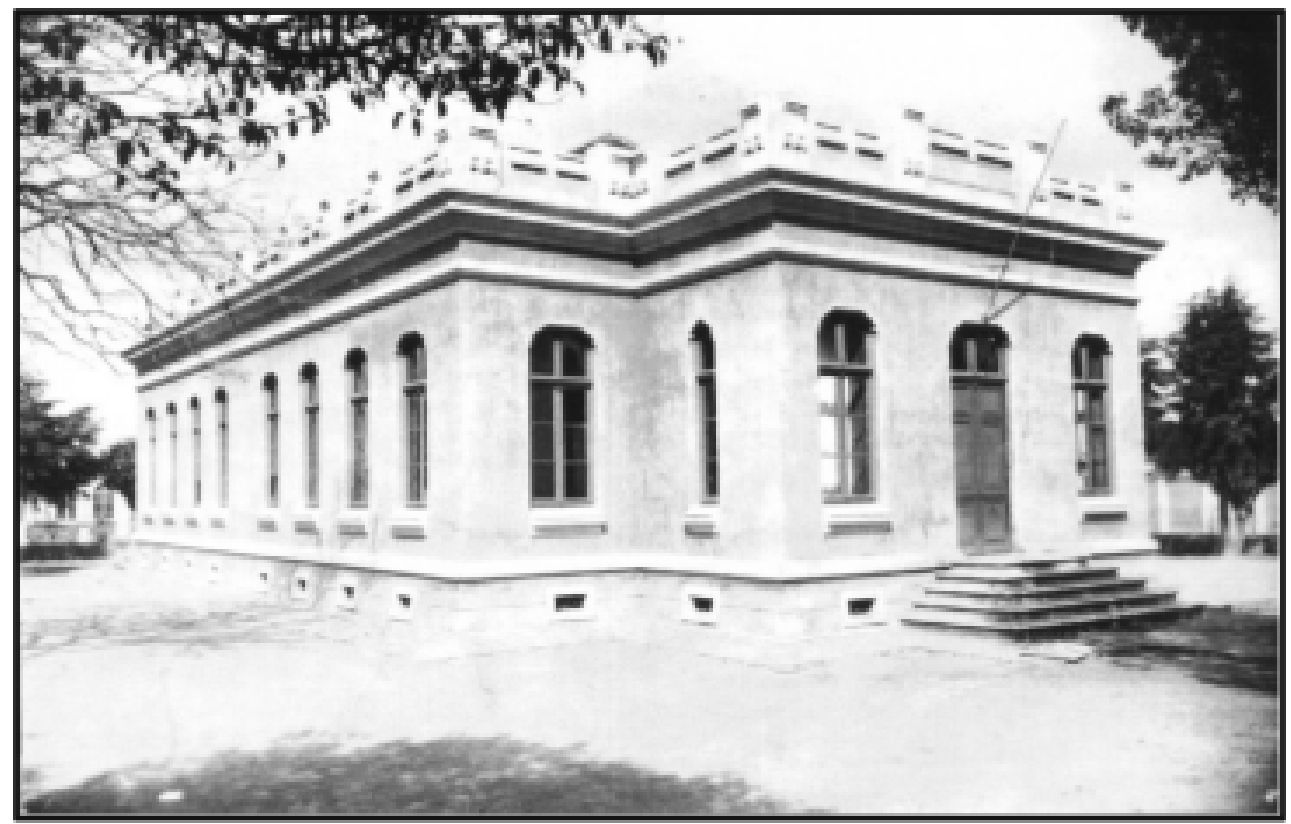

Foto 9 - Prédio do Grupo Escolar "Senador Correia” (1912) na Praça Roosevelt, s/no․

A foto permite a percepção de registro planejado, caracterizado pela atitude contida, indumentária especial, pose estudada, disposição dianteira do grupo feminino, os professores situados na retaguarda e ao alto. Poucos dos retratados encaram diretamente a câmera.

O grupo de professores repete os padrões vigentes da foto oficial no espaço externo, defronte o edifício que representa o seu labor profissional. 
A foto caracteriza-se pela uniformidade e pela expressão da identidade coletiva e expressa a supremacia do elemento feminino em atuação no ensino primário.

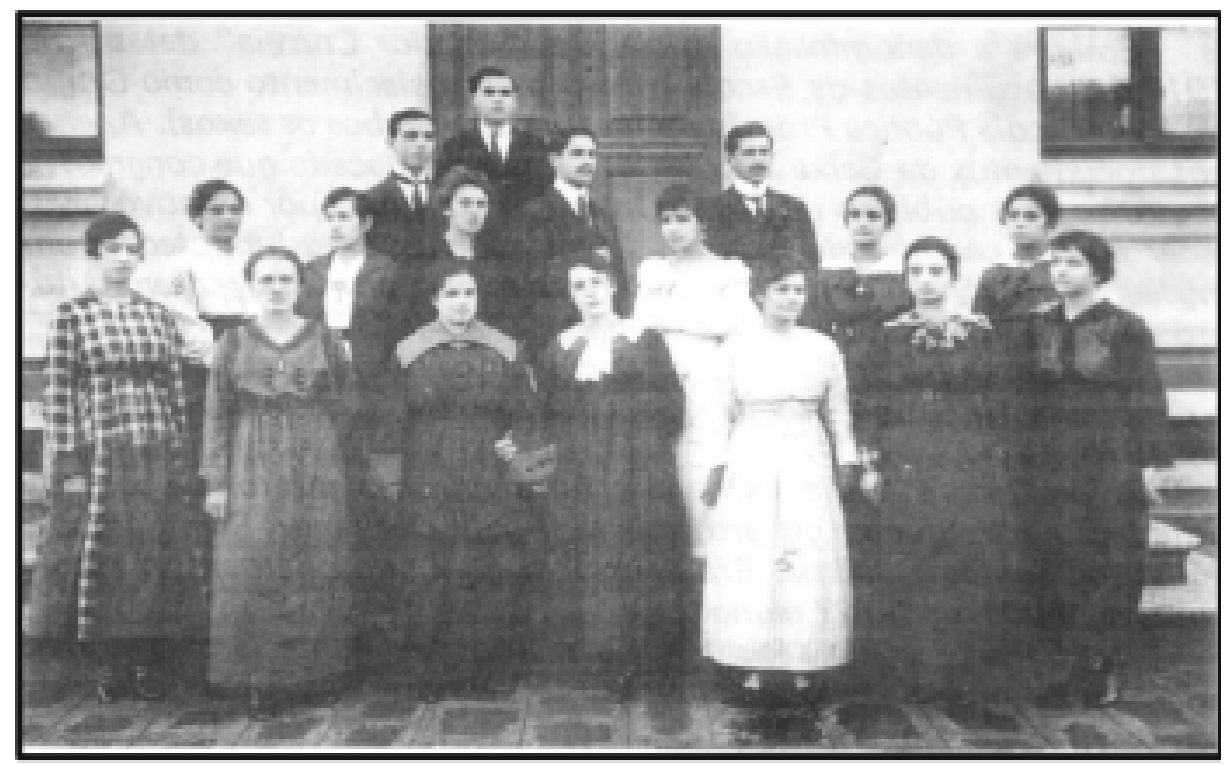

Foto 10 - Corpo docente do Grupo Escolar “Senador Correia” (1916)

A foto retrata a aplicação de atividades diversificadas, padrão dos princípios escolanovistas vigentes na década de 20-30: a escola ativa.

Os alunos, sob a supervisão da professora e sua auxiliar se empenham em atividades diferenciadas (observação), realizadas em pequenos grupos (experimentação), sob a supervisão docente definindo o papel central exercido pelo aluno na construção do seu conhecimento.

"Por escola nova - escrevia Lourenço Filho - se deve entender, hoje, um conjunto de doutrinas e princípios tendentes a rever, de um lado, os fundamentos da finalidade da educação; de outro, as bases de aplicação da ciência a técnicas educativas" (LOURENÇO FILHO citado por MONARCHA, p. 83). 
O discurso renovador ao mesmo tempo em que indicava transformações nas práticas escolares negava os saberes anteriormente vigentes: aprendizagem contrapunha-se a ensino, sendo a psicologia experimental o suporte para a cientificidade pedagógica.

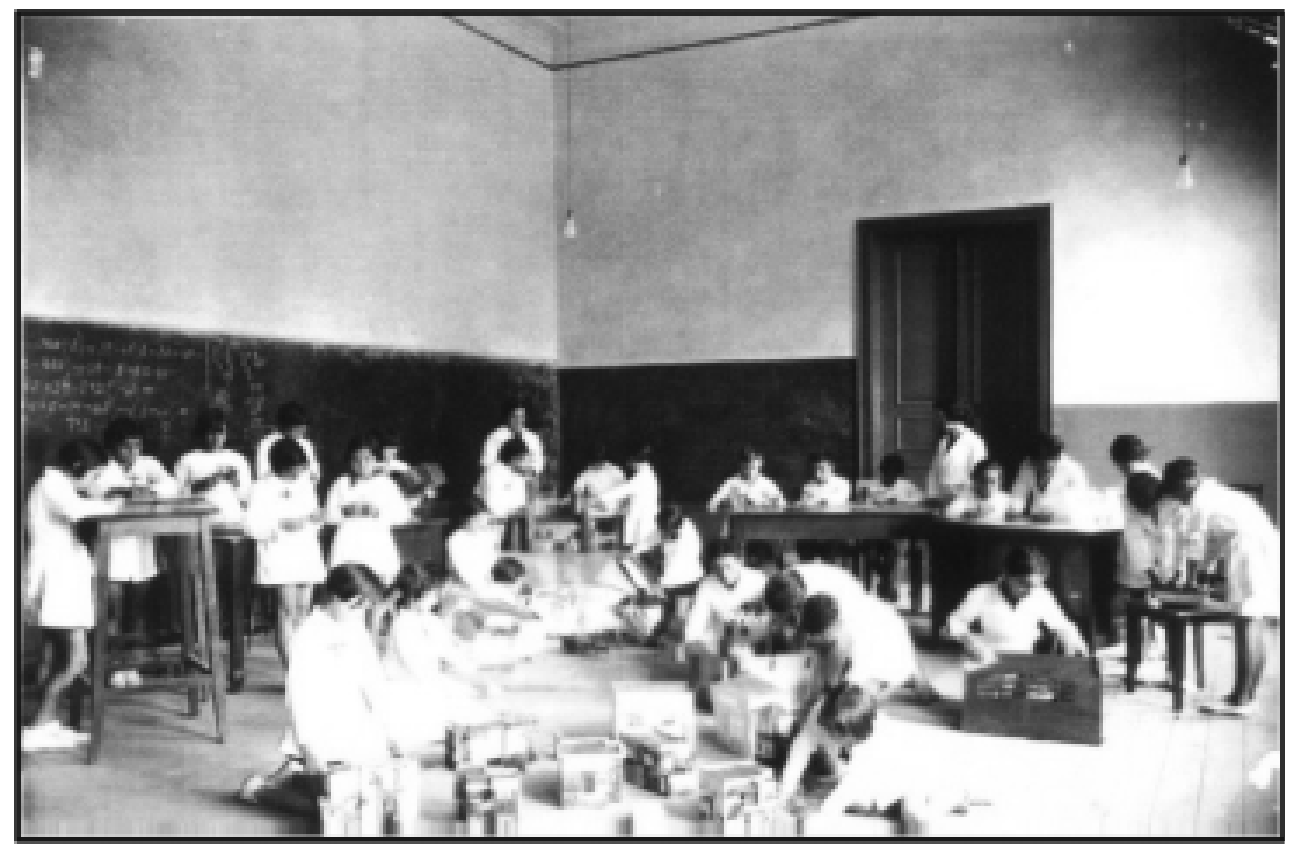

Foto 11 - Grupo Escolar "Senador Correia" - Sala de aula com desenvolvimento de atividades diversificadas (década de 1920).

A foto retrata o ambiente informal do período do recreio. Caracteriza-se por brincadeiras de época, no ambiente externo da escola sob a vigilante supervisão da professora que fiscaliza os alunos. Identifica a uniformidade presente no ambiente escolar pela utilização do avental e do gorro branco para alunos e guarda-pó branco para a professora.

Embora em momento descontraído expressa-se, subjacente, o controle dos folguedos numa perspectiva própria dos rituais escolares. É possível brincar com tempo e limites definidos; com ordem se promove a disciplinarização do corpo infantil. 


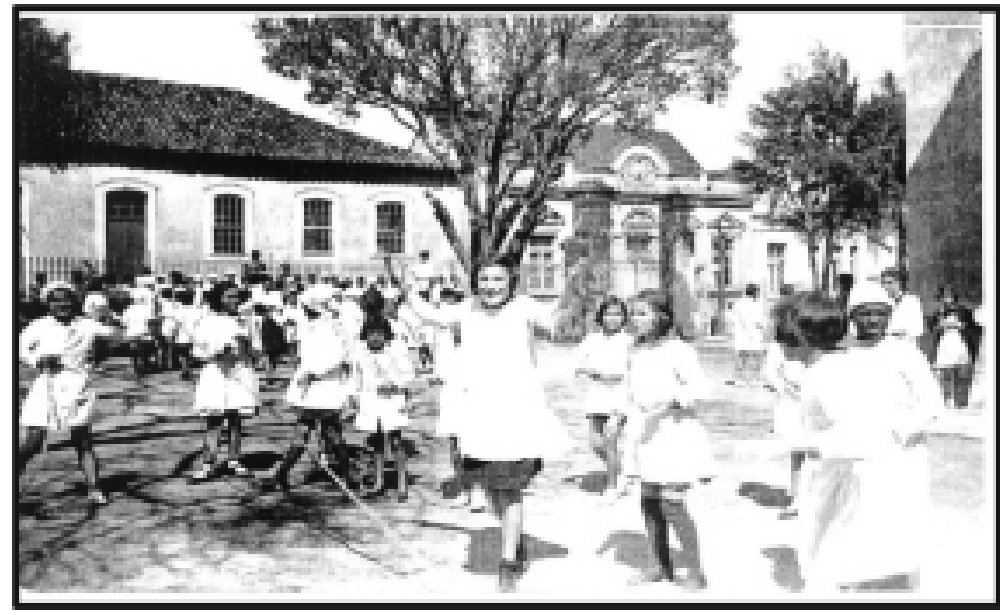

Foto 12 - Grupo Escolar "Senador Correia” - recreio (década 20-30)

\section{Considerações finais}

O contato com os arquivos escolares reitera, para o GT dos Campos Gerais do Paraná, várias das questões indicadas inicialmente.

Em primeiro lugar, a percepção de que os documentos classificados e catalogados representam "monumentos" que resistem a uma longa trajetória de descaso e descuido com a memória das instituições. Fato que desafia, especialmente, as equipes das escolas públicas, sempre às voltas com as mais diversas e, já amplamente denunciadas dificuldades, seja de caráter financeiro seja de recursos humanos.

Entretanto, essas circunstâncias representam exatamente os desafios que se procurou/procura enfrentar utilizando a construção da História Local/ Regional como suporte para a manutenção e registro das memórias escolares, promovendo a formação de pesquisadores na graduação e na pós-graduação, sendo esse um segundo fator a ser analisado.

A continuidade do desenvolvimento do projeto de preservação das fontes primárias e secundárias da educação brasileira na região depende de financiamento institucional, constantemente ameaçado pela lógica neoliberal (impensável num governo estadual peemedebista) que avoca para si a legitimidade e pragmatismo da produção do conhecimento nas universidades estaduais, desconsiderando a já tão combalida autonomia pedagógica das IES nesse contexto regional. 
Além disso, o avanço e o incremento da pesquisa educacional desenvolvida pelo GT aponta para uma segunda etapa, já em curso a partir do ano 2000, que se constitui na análise das fontes catalogadas e da formação dos pesquisadores para o trabalho com fontes documentais específicas, como a história oral, a imprensa e a fotografia, objeto da presente discussão.

Como se afirmou anteriormente, os procedimentos metodológicos para o trabalho com as narrativas imagéticas são possibilidades para a atividade historiográfica da educação, indicando a necessidade de tratamento e análise singulares. Como afirma Ortiz (1985), ao tratar do cinema, existem questões metodológicas a serem consideradas: o historiador deve apresentar uma consciência aberta para a interdisciplinaridade e deve assumir uma atitude de pesquisador-apaixonado. A primeira perturba a segurança do historiador, podendo resultar em trepidações do poder acadêmico; a segunda transforma-o pelo perigo da paixão em pesquisador-espectador que se deixa envolver conscientemente numa situação de experiência amorosa.

Assim, é presente a subjetividade de quem contempla e se encanta com uma mensagem do passado e, ao mesmo tempo, se esforça para produzir análises que se projetam para o interior da foto, tentando construir a sua leitura dentro do rigor metodológico, indicando a presença de significados que promovem a construção de sentidos históricos. Pois como afirma Ciavatta (op cit, p. 70),

como outras linguagens, a fotografia expressa a compreensão pelo olhar, pelos modos de ver, as relações. Se a imagem acompanha a vida humana como representação da realidade, como memória e expressão da cultura de um povo, de uma época, garantia de uma visão do passado, hoje, com a comunicação informatizada, ela nos desafia a compreendê-la em novas temporalidades, como mediação complexa dos processos educativos.

\section{Referências}

CHARTIER, R. A história cultural: entre práticas e representações. Lisboa: DIFEL, 1990.

CHAMMA, G. V. S. Ponta Grossa: a cidade, o povo e o poder. Ponta Grossa: Planeta, 1990. 
CIAVATTA, M. 0 mundo do trabalho em imagens: a fotografia como fonte histórica (Rio de Janeiro 1900-1930). Rio de Janeiro, RJ: DP\&A, 2002.

ESSUS, A. M. Sob o signo da imagem: a produção da fotografia e o controle dos códigos de representação da classe dominante, no Rio de Janeiro, na primeira metade do século XX. Niterói: Ed. da UFF, 1990.

HOLZMANN, G. V. S. Ponta Grossa: edição histórica. Curitiba: Requião, 1975.

LEITE, M. M. Retratos de família: leitura da fotografia histórica. São Paulo, SP: Edusp, 1993.

. Retratos da família: imagem paradigmática no passado e no presente. In: SAMAIN, E. (Org.). 0 fotográfico. São Paulo, SP: Hucitec, 1998.

LOPES, E. M. T.; GALVÃO , A. M. de. O História da educação. Rio de Janeiro, RJ: DP\&A, 2001.

LUPORINI, T. J. Pesquisando e compreendendo História: uma experiência com alunos de 8. ํㅗ́ie. Dissertação (Mestrado) - Programa de Pós-Graduação em Educação, Pontifícia Universidade Católica de São Paulo, 1989.

. Catálogo das fontes primárias e secundárias da educação localizadas na Região dos Campos Gerais do Pr. Ponta Grossa: Planeta, 1997.

. 10 ano s do HISTEDBR: a organização e criação do GT do Paraná. Revista Eletrônica do Histebr, Campinas, fev. 2003.

. De escola normal a instituto de educação: a trajetória de uma escola. Ponta Grossa: Imprensa Universitária/UEPG, 1994.

MONARCHA, C. A reinvenção da cidade e da multidão: dimensões da modernidade brasileira - a escola nova. São Paulo, SP: Cortez, 1989.

MORAES, C. S. V.; ALVES, J. F. (Orgs.). Escolas profissionais públicas do Estado de São Paulo: uma história em imagens (álbum fo tográfico). São Paulo, SP: IOESP, 2002.

OLIVEIRA JUNIOR, A. Do reflexo à mediação: um estudo da expressão fotográfica e da obra de Augusto Malta. 1994. Dissertação (Mestrado) Universidade Estadual de Campinas, Campinas, 1994.

ORTIZ, J. M. Relações cinema-história: perigo e fascinação. Projeto História, n. 4, p. 55-61, jun. 1985.

RODRIGUES, J. H. Teoria da história do Brasil: introdução metodológica. 5. ed. São Paulo, SP, 1978. 


\section{Anexo}

Cadastro de Documentos

Foto n. ${ }^{\circ} 1$

1. Nome do autor: Raul Bianchi

2. Modo de aquisição: compra

3. Tipo do documento: fotografia

4. Material do suporte: papel Ektalure

5. Formato: $18 \times 24$

6. Legibilidade do original: excelente

7. Procedência do original: Foto Bianchi

8. Local e endereço em que foi produzido o original: Foto Bianchi

9. Endereço: Rua Sete de Setembro, no 592 - Ponta Grossa-PR

10. Observações sobre o documento: Negativos - chapas de vidro

11. Descrição do documento: a foto retrata o corpo docente da Escola de Aplicação anexa à Escola Normal Primária de Ponta Grossa; ao centro: professor Joaquim Meneleu de Almeida Torres (diretor), em 1924; também se encontra presente o professor Jacques Corneau; não há identificação das professoras fotografadas.

Obs.: como nos demais documentos repetem-se os itens de 1 a 10, foram especificados apenas a descrição das fotos de no 2 a 13.

\section{Foto n. ${ }^{\circ} 2$}

11. Descrição do documento: a foto retrata a sala da Congregação da Escola Normal de Ponta Grossa -1924

\section{Foto n. ${ }^{\circ} 3$}

11. Descrição do documento: a foto retrata a fachada do prédio em que funcionou a Escola Normal de Ponta Grossa a partir de 1939.

\section{Foto n. ${ }^{\circ} 4$}

11. Descrição do documento: a foto retrata a perspectiva do fundo prédio, incluindo o pátio (1939).

\section{Foto n. ${ }^{\circ} 5$}

11. Descrição do documento: a foto retrata a entrada do saguão da Sala da Congregação da Escola Normal a partir da visão da escadaria que a ela conduzia (1939). 


\section{Foto n. ${ }^{\circ} 6$}

11. Descrição do documento: a foto retrata a entrada central da Escola Normal (1939) e a escadaria que conduz ao primeiro andar.

\section{Foto n. ${ }^{0} 7$}

11. Descrição do documento: a foto retrata o saguão propriamente dito, o qual constituía a ante-sala da Sala da Congregação da Escola Normal (1939).

\section{Foto n. ${ }^{\circ} 8$}

11. Descrição do documento: a foto retrata a Sala da Congregação da Escola Normal (1939).

\section{Foto n. ${ }^{\circ} 9$}

11. Descrição do documento: a foto retrata o prédio do Grupo Escolar "Senador Correia" (1912) na Praça Roosevelt, s/nํㅜ.

\section{Foto n..$^{\circ} 10$}

11. Descrição do documento: a foto retrata o corpo docente do Grupo Escolar "Senador Correia" (1916).

\section{Foto n..$^{0} 11$}

11. Descrição do documento: a foto retrata a sala de aula com desenvolvimento de atividades diversificadas do Grupo Escolar "Senador Correia" (década de 1920).

\section{Foto n..$^{\circ} 12$}

11. Descrição do documento: a foto retrata recreio no Grupo Escolar "Senador Correia" (década 20-30) 